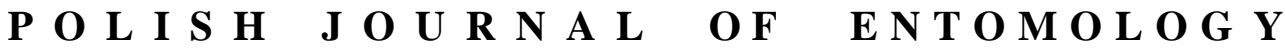

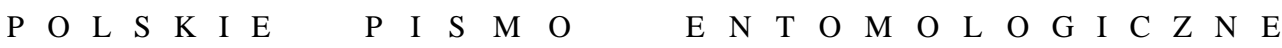

VOL. 87: 65-75

Lublin

31 March 2018

DOI: $10.2478 /$ pjen-2018-0005

\section{First record of Stenopelmus rufinasus GYLLENHAL, 1835 (Coleoptera: Curculionidae) from Poland}

\author{
MAREK WANAT ${ }^{*}$ \\ Museum of Natural History, University of Wrocław, Sienkiewicza 21, 50-335 Wrocław, \\ Poland
}

\begin{abstract}
Stenopelmus rufinasus, a North American weevil introduced to Europe along with the invasive aquatic fern Azolla filiculoides, has been recorded from Poland for the first time. Its locality is a natural oxbow lake of the River Odra in Wrocław, the only city in Poland where $A$. filiculoides has been repeatedly recorded over the last dozen years. The diagnostic characters of this weevil species, its biology, current distribution in Europe and its prospects in Poland are discussed.

KEY WORDS: Weevils, Erirhininae, Tanysphyrini, adventive species, Azolla filiculoides, new record.
\end{abstract}

\section{INTRODUCTION}

The monotypic genus Stenopelmus SCHOENHERR, 1835 is the type genus of a group of tribal rank, including mainly American and Australo-Pacific genera of weevils predominantly associated with aquatic habitats (ALONSO-ZARAZAGA \& LYAL 1999), finally synonymized with the tribe Tanysphyrini GISTEL, 1848 (OBERPRIELER 2014). It belongs to the curculionid subfamily Erirhininae SCHOENHERR, 1825, sometimes regarded as a distinct family (e.g. THOMPSON 1992, CALDARA 2011) or a subgroup of another weevil subfamily Brachycerinae BILlBERG, 1820 (e.g. OBERPRIELER et al. 2007, BOUCHARD et al. 2011, OBERPRIELER 2014) in the still largely unstable phylogenetic systematics of true weevils (Curculionidae s. lato).

\footnotetext{
* Corresponding author: marek.wanat@uwr.edu.pl
} 
Stenopelmus rufinasus GYLLENHAL, 1835 is indigenous to the southern and western USA (O'BRIEN \& WIBMER 1982, O'BRIEN \& ANDERSON 1996), but it was recorded in Europe as early as the late $19^{\text {th }}$ century, first of all in France, and erroneously described under a different name Degorsia champenoisi by BEDEL (1902). Since then the weevil has been recorded in other European countries, e.g. the United Kingdom (JANSON 1921), Germany (MANZeK 1927), Hungary (Podlussány 2001), Spain (FernándeZ CARILlo et al. 2005), Slovakia (STEJSKAL 2012) and Serbia (PEŠIĆ 2014). The current European distribution of S. rufinasus was summarized in the Cooperative Catalogue of Palaearctic Coleoptera Curculionoidea (ALONSO-ZARAZAGA et al. 2017), but to this should be added the most recent new record from Israel (FRIEDMAN 2017).

This weevil is biologically associated with aquatic ferns of the genus Azolla LAM., primarily with Azolla filiculoides LAM., which has become a cosmopolitan and invasive weed all over the world in the $20^{\text {th }}$ and $21^{\text {st }}$ centuries as a result of human activity (RICHERSON \& GRIGARICK 1967, HILL 1998, WEBER 2005): this has been decisive for the subsequent expansion of S. rufinasus outside North America. While its presence in Europe is the result of unintentional introduction together with the fern over a century ago, the weevil was imported to South Africa, where it was released in 1997 with the intention of controlling the invasive Azolla filiculoides (MCCONNACHIE et al. 2003, 2004, HILL et al. 2008, HiLL \& MCCONNACHIE 2009).

Because of the long-documented occurrence of S. rufinasus in Germany (MANZEK 1927), its recent discovery in Slovakia (STEJSKAL 2012), and finally, the well-documented presence of its host plant in Poland (SZCZÉŚSIAK et al. 2009), the weevil has been anticipated in this country. Ultimately, it was discovered in the only area in Poland where Azolla filiculoides has been regularly observed in the last ten years.

\section{RESULTS}

\section{Record}

Stenopelmus rufinasus was found on a small, natural oxbow lake of the River Odra in the Pilczyce Forest, near the Kozanów housing estate (51.154537N/16.972923E, UTM $10 \times 10 \mathrm{~km}$ grid cell XS36). The author sifted a total of 17 overwintering specimens from detritus on the oxbow lake shore on $27^{\text {th }}$ February 2017. The elongated oxbow lake is bordered by a forested floodbank to the south and is currently separated into two parts by a low dike. The shores of both these parts were sampled separately: S. rufinasus was present only in the sample taken from the south-eastern corner of the eastern pond (about five metres of the shoreline were sampled). 
All the voucher specimens are in the author's collection, which is deposited at the Museum of Natural History, University of Wrocław.

\section{Morphology}

As Stenopelmus rufinasus is not mentioned in the keys for identifying Polish weevils published in the $20^{\text {th }}$ century by SMRECZYŃSKI $(1972,1976)$, brief diagnostic morphological characteristics of this species are provided below. At first glance, the weevil resembles the ceutorhynchine Phytobiini because of the relatively compact elytra and short, thick rostrum (Fig. 1), possibly also small species of Bagoini, but it is readily distinguishable from both these weevil groups by the following set of external characters.

Body length (rostrum excluded) 1.8-2.3 mm. Integument black except for testaceous distal half of rostrum, antennae and tibiae; tarsi and femora dark brown. Body densely covered with roundish ochraceous and white scales mixed in various proportions, forming a marbled pattern on elytra. Underside of entire body densely and uniformly covered with white to cream scales. Rostrum thick, not more than $1.5 \times$ as long as wide and distinctly shorter than pronotum, in dorsal outline slightly narrowed at mid-length, in lateral view narrowed apicad from antennal insertion; apex, besides a pair of dorsal epistomal setae, with a long, protruding seta on each side (Fig. 2). Antennae short, inserted dorsally to rostrum. Scrobes straight, ending below ventral margin of eye, well visible in dorsal view (Fig. 3). Eyes nearly flat. Frons at narrowest point between eyes 0.7 as wide as rostrum base. Pronotum tapering from base to apical margin, with obsolescent subapical constriction, densely punctured, without prescutellar fovea, instead with a short and fine median carina. Mesepimera concealed in dorsal view. Scutellum covered with white scales. Elytra ca. 1.3 times longer than wide, much wider than pronotum, sub-parallelsided on basal two-thirds of length, then broadly rounded, with prominent humeri each associated with a spot of white scales. Legs slender, fairly long; femora unarmed; all tibiae with a thin uncus (Fig. 4); tarsi slender, the $2^{\text {nd }}$ segment distinctly shorter than $1^{\text {st }}$ and $3^{\text {rd }}$ ones, the $3^{\text {rd }}$ segment only slightly wider than the two preceding ones; onychium with long simple claws and a minute median process (empodium?) between them, bearing two long hair-like setae (Fig. 5).

The peculiar structure of the tarsi in Stenopelmus beetles seems to be an adaptation to water surface walking, not to swimming. RICHERSON \& GRIGARICK (1969) first confirmed the ability of Stenopelmus weevils to walk across the water surface film, but they never observed the beetles swimming or crawling beneath the water surface. 


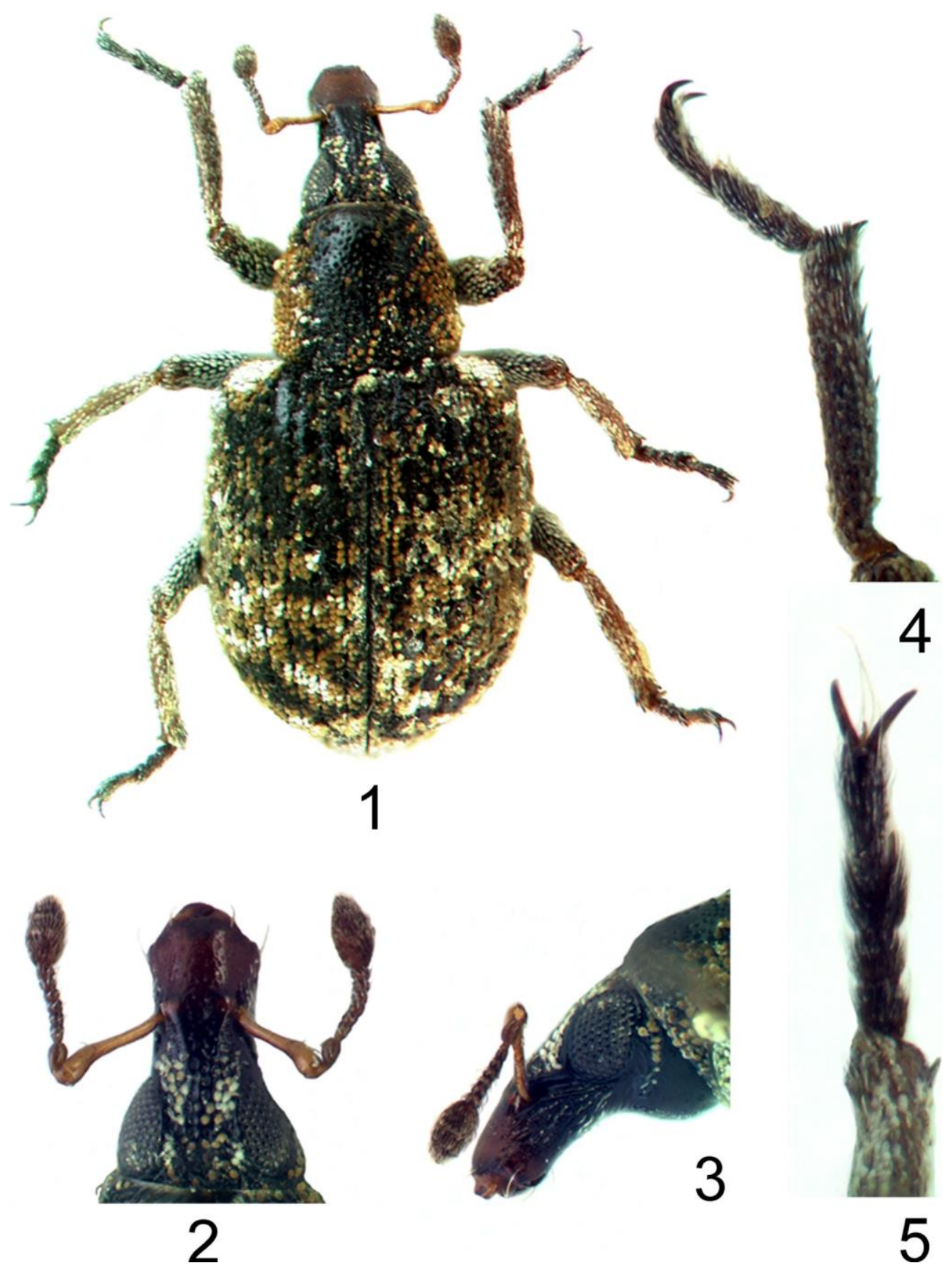

Fig. 1-5. Stenopelmus rufinasus: 1. habitus (length of beetle $1.9 \mathrm{~mm}$ without rostrum). 2. head, dorsal view; 3. head, lateral view. 4. protibia and protarsus; 5. mesotarsus. 


\section{DISCUSSION}

The life history of Stenopelmus rufinasus was studied in the laboratory by RICHERSON \& GRIGARICK (1967) and HILL (1998). Noteworthy is the very fast larval development, lasting about 7 days at room temperature. Its life cycle, including the time of hatching and the pupal period, takes no longer than about 20 days to complete, which yields 4-6 generations a year under Californian climatic conditions (RICHERSON \& GRIGARICK 1967). This is probably the main reason for the spectacular efficiency of S. rufinasus in controlling the invasive red water fern, and even completely eradicating its host plant (HILL et al. 2008).

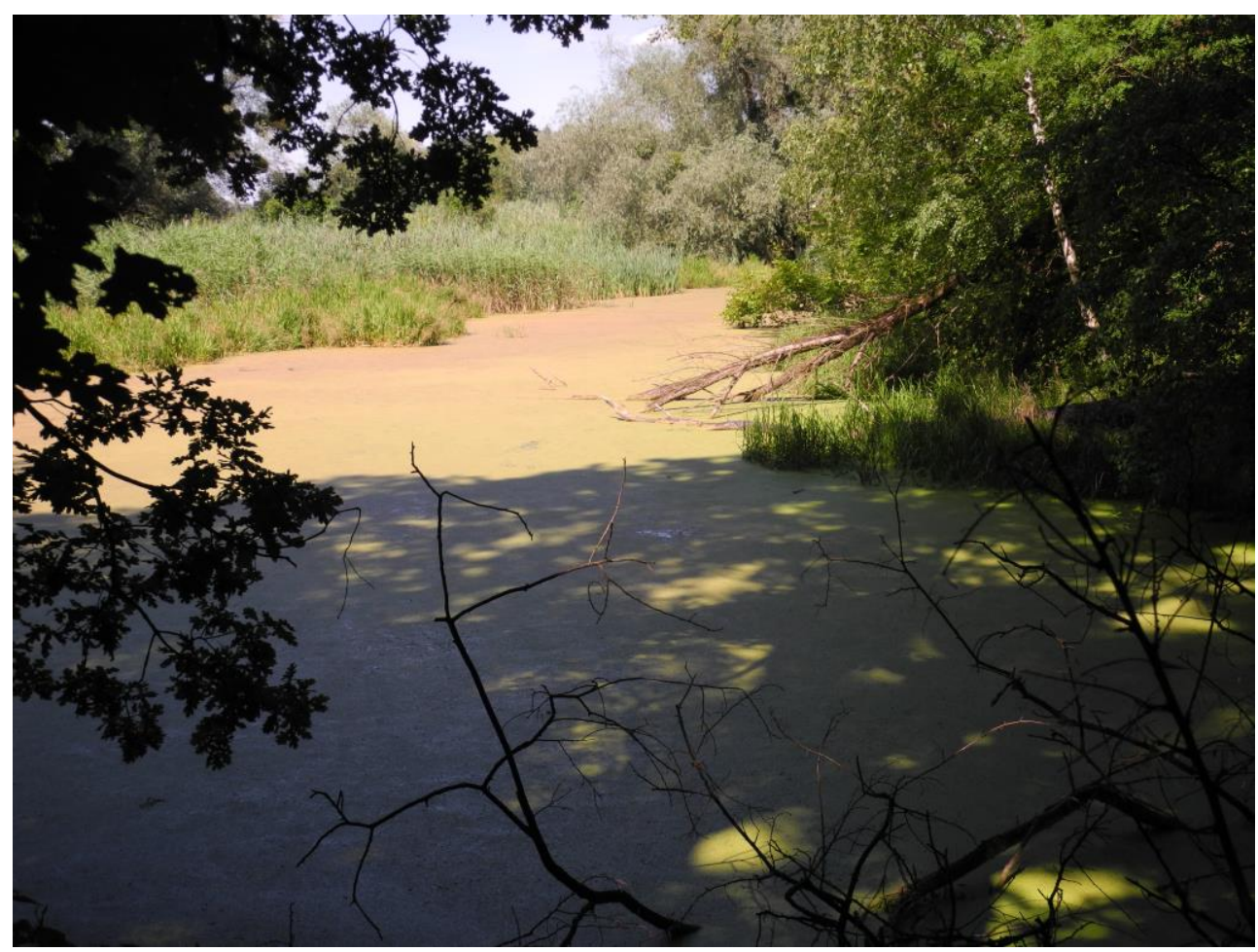

Fig. 6. The site of Stenopelmus rufinasus in the Pilczyce Forest, Wrocław (photo taken on 18 July 2017). 
No Azolla was recorded before from the site where Stenopelmus was discovered, but as the sifted sample was taken before the growing season, there was no opportunity then to see live ferns. However, the number of beetles collected clearly indicates that this finding was not accidental and the weevil must almost certainly have developed in situ. The presence of Azolla in this and neighbouring oxbow lakes was finally confirmed in July 2017 (Fig. 6). The occurrence of this fern on another oxbow lake in the Kozanów housing estate, approximately $1.5 \mathrm{~km}$ distant from the Stenopelmus locality in the Pilczyce Forest, has been documented since 2007, and temporarily in the nearby small pond even as early as 1996 (SZCZÉŚSIAK et al. 2009). As often happens to Azolla stands in Wroclaw, the fern has apparently become extinct there in recent years (E. SZCZĘŚSIAK pers. comm.). According to SZCZEŚSIAK et al. (2009), it was then one of the three localities of the red water fern in Lower Silesia, and also in Poland as a whole. Although its presence in this region was first noticed well before World War II (SCHUBE 1928), and outside Silesia, once in Bielsk Podlaski in north-east Poland (WOŁKOWYCKI 1999), both these records were confined to artificial ponds and were thus ephemeral, like one of the two localities in Wrocław discovered in the $21^{\text {st }}$ century (the fire protection pond in Wilkszyn).

The time and nature of the migration of Stenopelmus migration to Wrocław remain unclear. In the countries bordering south-west Poland, Azolla filiculoides is a common invasive plant in Germany, but is as yet unknown in Czechia (HUSSNER 2010); in Slovakia it was first found in the western part of the country in 2011 (STEJSKAL 2012). There is a European record of S. rufinasus feeding on Salvinia natans (L.) ALL. (RHEINHEIMER \& HASSLER 2010), an aquatic fern long known and widely distributed in Poland in the basins of the Rivers Vistula and Odra (ZAJĄC \& ZAJĄC 2001). The feeding of this weevil on another species of Salvinia, S. minima BAKER, was confirmed in the USA by PARYS \& TEWARI (2015), and its development on another Azolla species - A. pinnata R. BR. - in Florida was documented by PEMBERTON \& BODLE (2009). STEJSKAL (2012) reported large numbers of $S$. rufinasus which had been sifted on the Île d'Oléron (southwest France) by R. SUIKAT, even though Azolla does not grow on this island. There are also regular records of single specimens of $S$. rufinasus sifted on the coast of SchleswigHolstein or at an altitude of $1600 \mathrm{~m}$ in France (STEJSKAL 2012). Hence, it is not at all clear that this adventive weevil is a strict monophage of Azolla filiculoides in Europe.

The closest recently confirmed sites of Stenopelmus are in western and northern Germany (DIECKMANN 1983, ZIEGLER 2017) and western Slovakia (STEJSKAL 2012), all of which are some considerable distance from Wrocław $(330-540 \mathrm{~km})$. The first German record by MANZEK (1927) was from the vicinity of Magdeburg, not very far from the western border of Poland (200 km), but some $400 \mathrm{~km}$ from Wrocław. According to German botanists, Azolla filiculoides had become extinct there before 1960 and the occurrence of $S$. rufinasus in that locality was not confirmed during a search in the 1970s (DIECKMANN 
1983). The Azolla fern may be passively transported to new localities, primarily by aquatic birds or humans (MOORE 1969). Hence, the associated accidental transportation of Stenopelmus larvae or pupal cocoons to new sites cannot be ruled out. However, I consider another possible explanation of the successful long distance dispersal of Stenopelmus beetles much more likely, following the opinion of P. SPRICK in STEJSKAL (2012) and resulting from their biology. Stenopelmus itself has a strong migration potential, as it is capable of locally producing several generations a season, thus achieving a very large number of individuals (according to HILL et al. (2008) >30 000 adult weevils were reared from $2 \mathrm{~m}^{2}$ of rotting red water fern mat in South Africa), which are forced to seek new Azolla stands after the eradication or at least a very significant reduction in the host plant at the end of the season. Field studies in South Africa showed S. rufinasus to be capable of very effective short-distance dispersal, enabling it to find most Azolla mats within a distance of up to $20 \mathrm{~km}$, but also of long-distance dispersal up to $350 \mathrm{~km}$ (MCCONNACHIE et al. 2004, HILL et al. 2008). This is a distance approximating that between Wrocław and the nearest published localities of S. rufinasus in Germany and Slovakia; hence, the weevil might well have found the sites of A. filiculoides in Wrocław by itself. This is especially likely given the probably very incomplete knowledge of the real distribution of $S$. rufinasus in Germany, where its host plant is common (HUSSLER 2010), and in Poland, where A. filiculoides was found in 2007, besides Wrocław, by the River Nysa Łużycka near Koźlice, on the border between Germany and Poland (SZCZĘŚNIAK et al. 2009).

The strong potential of $S$. rufinasus for migration is indirectly confirmed by its frequent and abundant flights to light traps installed many kilometres from any water bodies, which I observed in KwaZulu-Natal province (north RSA) in 2012. It is still not known whether Stenopelmus beetles have any sensory adaptations facilitating the active search for water bodies or whether they are just passively carried by winds, successful migration depending simply on the long-distance dispersal of large numbers of these insects. The records from the coasts of the Île d'Oléron and Schleswig-Holstein mentioned by STEJSKAL (2012) favour neither of these two hypotheses.

As regards the European range of $S$. rufinasus, the newly discovered locality in Wrocław appears to be the most northerly one in central Europe (excepting western Germany). Further east it is known only from Slovakia, Hungary, Serbia and Ukraine (CAldara 2011, Alonso-ZaraZAGa et al. 2016, 2017). The weevil inhabits more northerly areas of western Europe, including Belgium, Great Britain and Ireland (ALONSOZARAZAGA et al. 2017), which have a typically Atlantic climate with mild winters. It thus follows the biological limitations of its host plant, which cannot withstand long, freezing winters (JANES 1998), and is therefore unable to form stable, long-lasting populations in central and eastern Europe; these are either non-existent or at best ephemeral. In Poland the red water fern has the status of a non-established species (HUSSNER 2010) and propagates 
only vegetatively (SZCZĘŚSIAK et al. 2009). Its stands in Wrocław are ephemeral, often lasting just one or two seasons regardless of whether the water body is natural or artificial (E. SZCZEŚSIAK pers. comm.). Severe frosts persisting for several days at least are a regular occurrence here almost every year; Azolla can survive such cold spells only if it produced a thick mat during the previous growing season (JANES 1998); but such mats are often removed, either when artificial ponds are cleaned or natural oxbow lakes are flooded (E. SZCZĘŚSIAK pers. comm.). Given this rather precarious position of its host plant in Wrocław, the occurrence of S. rufinasus there may well turn out to be ephemeral as well. On the other hand, the activity of Stenopelmus may to some extent itself contribute to the instability of the red water fern stands in Wrocław, but this problem requires further study, and above all, a better knowledge of the distribution of S. rufinasus and A. filiculoides in this city.

\section{CONCLUSIONS}

A weevil species new to the Polish fauna, Stenopelmus rufinasus, was found on a natural oxbow lake of the River Odra in Wrocław. It is associated with the red water fern Azolla filiculoides. With the exception of two incidental historical records from ephemeral sites, this invasive fern has recently been recorded from Poland only in Lower Silesia, at less than 10 localities during the last 20 years, the great majority from Wroclaw (SZCZĘŚNIAK et al. 2009, SZCZĘŚNIAK pers. comm.). Although the localities of this plant are highly ephemeral, persisting for just a few years, new ones are regularly being discovered in Wrocław (SZCZĘŚSIAK pers. comm.). In view of the status of A. filiculoides in Wroclaw, the migration of Stenopelmus to Poland must have been relatively recent and may well turn out to have been ephemeral. This weevil appears to have the potential to migrate, extending its range at least within south-western Poland, but it is a specialized herbivore, strictly dependent on the migration success of its main host plant.

\section{ACKNOWLEDGEMENTS}

I am greatly indebted to Dr Ewa SzCZĘŚNIAK (Department of Botany, Institute of Environmental Biology, Faculty of Biological Sciences, University of Wrocław) for information on the current status of Azolla filiculoides in Wrocław. I am also grateful to the three anonymous reviewers for their valuable suggestions for improving this paper. $\mathrm{Mr}$. Peter SENN is thanked for his thorough work on the language of this paper. 


\section{REFERENCES}

Alonso-Zarazaga M.A., Barrios H., Borovec R., Bouchard P., Caldara R., Colonnelli E., Gültekin L., Hlaváč P., Korotyaeev B.A., Lyal C.H.C., Machado A., Meregalli M., Pierotti H., Ren L., SÁnchez-Ruiz M., Sforzi A., SilfVerberg H., Skuhrovec J., Trýzna M., VelázQuez de Castro A.J., Yunakov N.N. 2017. Cooperative Catalogue of Palaearctic Coleoptera Curculionoidea. Sociedad Entomológica Aragonesa, Monografias electrónicas SEA, 8, www.sea-entomologia.org, November 2, 2017.

Alonso-Zarazaga M.A., Caldara R., Machado A., Maughan N., Pelletier J., Pierotti H., Ren L., Sforzi A., Silfverberg H., Skuhrovec J. 2016. Addenda and Corrigenda to the Catalogue of Palaearctic Coleoptera, Volumes 7 and 8 (Curculionoidea). Graellsia, 72(1): 1-42.

Alonso-Zarazaga M.A., Lyal C.H.C. 1999. A World Catalogue of Families and Genera of Curculionoidea (Insecta: Coleoptera) (Excepting Scolytidae and Platypodidae). Entomopraxis, Barcelona.

BEDEL L. 1902. Description et moeurs d'un nouveau genre de Curculionides de France. Bulletin de la Société Entomologique de France 6: 358-359.

Bouchard P., Bousquet Y., Davies A.E., Alonso-Zarazaga M.A., Lawrence J.F., Lyal C.H.C., Newton A.F., Reid C.A.M., Schmitt M., Ślipiński S.A., Smith A.B.T. 2011. Family-group names in Coleoptera (Insecta). ZooKeys 88: 1-972.

CALdARA R. 2011. Erirhinidae. [in:] I. LöBl, A. Smetana (eds.). Catalogue of Palaearctic Coleoptera, Volume 7. Curculionoidea I. Apollo Books, Stenstrup, 192-198.

DiECKMANN L. 1983. Beiträge zur Insektenfauna der DDR: Coleoptera - Curculionidae (Tanymecinae, Leptopiinae, Cleoninae, Tanyrhynchinae, Cossoninae, Raymondionyminae, Bagoinae, Tanysphyrinae). Beiträge zur Entomologie 33(2): 257-381.

Fernández Carillo J.L., Fernández Carillo E., Alonso-Zarazaga M.A. 2005. Primera cita de Stenopelmus rufinasus GYLLENHAL, 1835 en la Península Ibérica (Coleoptera, Erirhinidae). Graellsia 61(1): 139-140.

Friedman A.-L.-L. 2017. The first record of the Azolla frond weevil Stenopelmus rufinasus (Curculionidae: Brachycerinae: Tanysphyrini) in Israel. Israel Journal of Entomology 47: 103-106.

HiLl M.P. 1998. Life history and laboratory host range of Stenopelmus rufinasus, a natural enemy of Azolla filiculoides in South Africa. BioControl 43(2): 215-224.

HiLl M.P., McConnachie A.J. 2009. Azolla filiculoides LAMARCK (Azollaceae). [in:] R. MuniaPPAN, G.V.P. REDDY, A. RAMAN (eds.). Biological Control of Tropical Weeds using Arthropods. Cambridge University Press, Cambridge, 74-87.

Hill M.P., McConnachie A.J., Byrne M.J. 2008. Azolla filiculoides Lamarck (Pteridophyta: Azollaceae) control in South Africa: a 10-year review. [in:] M.H. Julien, R. SFORZA, M.C. Bon, H.C. Evans, P.E. Hatcher, H.L. Hinz, B.G ReCtor (eds.). Proceedings of the XII International Symposium on Biological Control of Weeds, La Grande Motte, France, 22-27 April 2007. CAB International, Wallingford, UK, 558-560. 
HusSner A. 2010: NOBANIS - Invasive Alien Species Fact Sheet - Azolla filiculoides. [in:] Online Database of the European Network on Invasive Alien Species - NOBANIS. Internet: www.nobanis.org (date of access 20/12/2017)

JANES R. 1998. Growth and survival of Azolla filiculoides in Britain: I. Vegetative reproduction. New Phytologist 138(2): 367-375.

JANSON O.E. 1921. Stenopelmus rufinasus GyLl., an addition to the list of British Coleoptera. The Entomologist's Monthly Magazine 57: 225-226.

MANZEK E. 1927. Stenopelmus rufinasus GyLl., ein für Deutschland neuer Käfer. Entomologische Blätter 23(4): 189-191.

McConnachie A.J., DE Wit M.P., Hill M.P., Byrne M.J. 2003. Economic evaluation of the successful biological control of Azolla filiculoides in South Africa. Biological Control 28(1): $25-32$.

McConnachie A.J., Hill M.P., Byrne M.J. 2004. Field assessment of a frond-feeding weevil, a successful biological control agent of red waterfern, Azolla filiculoides, in southern Africa. Biological Control 29(3): 326-331.

Moore A.W. 1969. Azolla: Biology and Agronomic Significance. The Botanical Review 35(1): $17-34$.

OberPRIELER R.G. 2014. Brachycerinae Billberg, 1820. [in:] R.G. Beutel, R.A.B. Leschen (eds.) Handbook of Zoology, Coleoptera Volume 3: Morphology and Systematics (Chrysomeloidea, Curculionoidea). Walter de Gruyter, Berlin, 424-451.

Oberprieler R.G., MARvaldi A.E., ANDERSon R.S. 2007. Weevils, weevils, weevils everywhere. [in:] Z.-Q. ZHANG, W.A. SHEAR (eds.). Linnaeus Tercentenary: Progress in Invertebrate Taxonomy. Zootaxa 1668: 491-520.

O'Brien C.W., ANDERson R. 1996. A catalog of the Coleoptera of America North of Mexico. Family: Curculionidae, subfamily Erirhininae. United States Department of Agriculture, Agriculture Handbook no. 529-143f. United States Department of Agriculture, Washington, D.C.

O'BRIEN C.W., WiBMER G.J. (1982): Annotated checklist of the weevils (Curculionidae sensu lato) of North America, Central America, and the West Indies (Coleoptera: Curculionoidea). Memoirs of the American Entomological Institute 34: i-ix +1-382.

Parys K.A., TEWARI S. 2015. Adults of the Waterfern Weevil, Stenopelmus rufinasus GylLENHAL (Coleoptera: Curculionidae), Feed on a Non-Host Plant, Salvinia minima BAKER, in Louisiana. The Coleopterists Bulletin 69(2): 316-318.

Pemberton R.W., Bodle J.M. 2009. Native North American Azolla weevil, Stenopelmus rufinasus (Coleoptera: Curculionidae), uses the invasive Old World Azolla pinnata as a host plant. Florida Entomologist 92(1): 153-155.

PEŠIĆ S. 2014. A review of weevils (Coleoptera, Curculionoidea) in the Zasavica Special Nature Reserve (Serbia). North-Western Journal of Zoology 10(2): 280-292.

PODLUSSÁNY A. 2001. Új ormányosalkatú bogárfajok Magyároszag faunájában (Coleoptera: Curculionoidea). Folia Entomologica Hungarica 62: 372-378. (in Hungarian)

RHEINHEIMER J., HASSLER M. 2010. Die Rüsselkäfer Baden-Württembergs. Naturschutz-Spectrum, Karlsruhe, Themen 99: 1-944. 
Richerson P.J., GRIGARICK A.A. 1967. The life history of Stenopelmus rufinasus (Coleoptera: Curculionidae). Annals of the Entomological Society of America 60(2): 351-354.

SCHUBE T. 1928. Ergebnisse der Durchforschung der schlesischen Gefässpflanzenwelt im Jahre 1927. Jahres-Bericht der Schlesischen Gesellschaft für vaterländische Cultur 101: 30-37.

SMRECZYŃSKi S. 1972. Keys for the Identification of Polish Insects, part 77, issue 98d. Beetles Coleoptera. Weevils - Curculionidae. Subfamily Curculioninae. Tribes Dryophthorini, Cossonini, Bagoini, Tanysphyrini, Notarini, Smicronychini, Ellescini, Acalyptini, Tychiini, Anthonomini, Curculionini, Pissodini, Magdalini, Trachodini, Rhynchophorini, Cryptorhynchini. PWN, Warszawa. (in Polish)

SMRECZYŃSKI S. 1976. Keys for the Identification of Polish Insects, part 87, issue 98f. Beetles Coleoptera. Weevils - Curculionidae. Subfamily Curculioninae. Tribes: Nanophyini, Mecinini, Cionini, Anoplini, Rhynchaenini and supplements to the issues 98 a - e. PWN, Warszawa. (in Polish)

STEJSKAL R. 2012. First record of Stenopelmus rufinasus GYLLENHAL, 1835 (Coleoptera: Erirhinidae) for Slovakia, with distribution and bionomic notes. Weevil News 74: 1-5.

Szczę́́niak E., BŁachuta J., Krukowski M., Picińska-FaŁtynowicz J. 2009. Distribution of Azolla filiculoides LAM. (Azollaceae) in Poland. Acta Societatis Botanicorum Poloniae 78(3): 241-246.

THOMPSON R.T. 1992. Observations on the morphology and classification of weevils (Coleoptera, Curculionoidea) with a key to major groups. Journal of Natural History 26(4): 835-891.

WeBer E. 2005. Invasive Plant Species of the World. CABI Publishing, Wallingford, UK.

WoŁKowyCKi D. 1999. Azolla filiculoides (Pteridophyta, Azollaceae) w Polsce. Fragmenta Floristica et Geobotanica, Seria Polonica 6: 165-170.

ZAJĄC A., ZAJĄC M. (eds.) 2001. Distribution Atlas of Vascular Plants in Poland. Laboratory of Computer Chorology, Institute of Botany, Jagiellonian University and Foundation of Jagiellonian University, Cracow.

ZIEGLER W. 2017. Stenopelmus rufinasus GYLLENHAL, 1836 - eine aus Mecklenburg-Vorpommern bisher unbekannte Käferart (Coleoptera: Curculionidae). Virgo 19(1): 84-86.

Received: 16 May 2017

Accepted: 3 January 2018 